\title{
Csızmadia Eruın
}

\section{Történelem. polıtılia és nemzetı habıtus \\ mıt mond a mának a mélymúlt?}

„A »múlt « a jelen világ meghatározott módon történő értelmezésének következménye”

(Michael Oakeshott: A történészi tevékenység)

Elöljáróban annyit mondanék, hogy nagyon kedvemre való témáról indított vitát a Replika, és ezért köszönettel tartozunk úgy a folyóiratnak, mint a vitaindító tanulmányt jegyző Hadas Miklósnak (Hadas 2018a). A köszönet elsősorban két dolognak szól. Az egyik, hogy Hadas olyan fogalmakat (magyar jellem, nemzeti habitus) hoz be elemzésébe, amelyek az elmúlt több mint negyedszázadban nemigen voltak elemzések tárgyai - talán azért, mert idejétmúltnak, meghaladottnak véltük őket. A másik, hogy a szerző - eszünkbe juttatva az 1980-as éveket - nagy történelmi tablón dolgozik és így kívánja alátámasztani érvelését, miszerint a magyar nemzeti habitus történelmi termék, ezért a mai korszakban történteket csak a történelem alapján lehet megérteni.

Magam politológus vagyok, s mint ilyen, pályafutásom kezdete óta a történeti politikatudomány híve. Régóta mondom, hogy az 1990 utáni folyamatokat (a demokrácia kiépülését, konszolidációját, majd visszafordulását) történeti szemlélettel, nagyobb folyamatokba ágyazottan tudjuk csak megérteni. Erről nemrégiben könyvet is írtam, amelyben részletesen beszélek a történeti politikatudományról mint műfajról; történészek és politikatudósok egymáshoz való viszonyáról, és egyáltalán: Magyarország hosszabb távú politikai fejlődéséről (Csizmadia 2017).

Örömömre szolgál tehát, hogy a szerző régebbi folyamatokat a maiakkal hasonlít össze, és ennek révén analógiákra (vagy homológiára) mutat rá. Sajnos a magyar politikatudományban - hogy csak saját szakmámról beszéljek - viszonylag ritkák az ilyen kísérletek. Ennek magyarázata egyfelől, hogy a politológusok eleve átadják a történeti terepet a történészeknek; másfelől azonban az, hogy a rendszerváltással kialakuló mainstream politikatu- 
domány éppen felváltotta az addig dominánsnak tekinthető s történeti alapon álló politológiát. Ahogy könyvemben is bemutatom: ez a politikatudomány döntően jelencentrikus, és a történelem mint magyarázó faktor tagadásának alapján áll. Az átmenetkor megerösödő tranzitológia (mert hiszen ez volt az újonnan domináns helyzetbe kerülő irányzat) intézményekre, a demokratizálás szereplőire kíváncsi, és nem nagyon érdeklik őt más szempontok (Csizmadia 2017: 62-68). Csak most, jó idővel a tranzitológia bukása után (Carothers 2002) látjuk azonban ennek az irányzatnak az egyoldalúságait, hiszen ez abból indult ki, hogy a demokratikus intézmények bárhol és bármikor létrehozhatóak s meghonosíthatóak, és a történelmi elöfeltételeket könnyedén meg lehet haladni, ha léteznek elszánt elitek.

A tranzitológia és a nyomába lépő egyéb mainstream politikatudományi iskolák végképp nem foglalkoztak és foglalkoznak olyan kérdésekkel, amelyeket Hadas fölvet, holott nagyon is érdemes lenne foglalkozni a történetileg kondicionált politikai magatartások kérdésével.

Mindezek előrebocsátásával igazán érdekes kihívás számomra hozzászólni egy történészszociológus tanulmányához. Remélem, a politológusi látásmód segítségével más optikák is feltárulnak.

\section{A nemzeti habitus és annak történeti-strukturális megközelítése: Hadas Miklós mélymúltértelmezése}

\section{A mélymúlt meghatározó ereje}

Hadas Miklós (2018a) dolgozata címében jelzi, hogy mondanivalóját az 1939-es Mi a magyar? címü, Szekfü Gyula által szerkesztett kötet inspirálta. Tanulmánya alcímében a téma „újratöltését” ígéri, de e kiindulóponthoz képest némi csalódás, hogy a kötetről a későbbiekben nem ejt szót, az abban írott tanulmányokat érdemileg nem vonja be elemzése körébe. Természetesen nem azt vártam volna a szerzőtől, hogy egy több mint 500 oldalas kötet tanulmányait egyenként elemezze, de azt igen, hogy legalább a kötetből kirajzolódó tanulságok egynémelyikét megemlítse. Persze az, hogy a „nemzeti habitust” választotta elemzése tárgyául, önmagában elismeréssel ér fel a kötet irányában.

A szerző kiinduló tétele, hogy nem is a múlt, hanem a „mélymúlt” határozza meg a jelent, s ez azt jelenti, hogy a manapság tapasztalható akár politikai viselkedésmódokat évszázadok alatt kialakult beállítódások formálják (Hadas 2018a: 154). Ezzel a kiindulóponttal nagymértékben egyetértek, azzal együtt is, hogy tudom: az ilyen megállapítások vitathatóak és empirikusan nehezen bizonyíthatóak. Hadd említsem meg, hogy Hadas nagyon hasonlót mond, mint az Acemoglu-Robinson-páros világhírü könyvében: „A ma létező, különböző intézményi minták mélyen a múltban gyökereznek, ugyanis, ha egyszer kialakul egy adott társadalmi berendezkedés, az általában hosszú időn át fennmarad” (Acemoglu-Robinson 2013: 49). Majd könyvük végén így összegeznek: „a történelmi folyamatok azok, amelyek - az intézményi szakadás révén - olyan különbségeket generálnak, amelyek kritikus fordulatok idején fontos következményekkel járhatnak" (Acemoglu-Robinson 2013: 410). Hadast - ahogyan Acemoglut és Robinsont is - a struktúrák izgatják, egészen pontosan az, hogy a struktúra mire kondicionál és mire nem. Természetesen ennél nem több a hason- 
lóság a két megközelítés között, hiszen az amerikai tudós kettős azt igyekszik bizonyítani, hogy a történelemben vannak alternatívák, és nincs elöre determinálva egy ország felemelkedése vagy éppen süllyedése. Hadas azonban nem lát alternatívákat a magyar fejlődésben, pontosabban azt látja, hogy mindig ugyanaz ismétlödik. Érdekes, hogy ugyanígy van ez az ellenpólusként említett Hollandiával is. Itt sincsenek alternatívák. Ahogyan Magyarország is nyílegyenesen ismétli önmagát, a hollandok is, csak náluk, szerencsés módon, a középkortól kezdődően egy strukturálisan kondicionált együttműködő és polgári magatartáskészlet halmozódott fel (Hadas 2018a: 154), amely aztán a holland fejlődés folyamatos kísérőjelensége egészen napjainkig (addig, hogy - Hadas példájával - egy átlag hollandnak eszébe nem jutna bliccelni a villamoson).

\section{Nemzeti habitus}

De most már lássuk, milyen definíciót ad a szerző arra a fontos - és általa rehabilitálni kívánt - fogalomra, amelyet nemzeti habitusnak nevezhetünk. Ezt írja: „a nemzeti habitus a mélymúltból származó összetett függőségi viszonyok által kondicionált viselkedési mintázatok összességeként ragadható meg” (Hadas 2018a: 155). Nem hagy kétséget afelöl, hogy a magyar nemzeti habitus kialakulását és fejlődését (mondhatni állandóságát) különféle strukturális háttérfeltételek befolyásolták. A két legfontosabb - ami elválasztotta Magyarországot a Nyugattól - a városiasság és a polgári értékek hiánya: Magyarországon a társadalmi gyakorlat a polgári mintázatokkal szemben határozza meg önmagát (Hadas 2018a: 156), és a városi létforma nem meghatározó strukturális tényező (Hadas 2018a: 158). Kiemeli továbbá, hogy Nyugat-Európában a zsidóság mintázata is a polgári erénykánonba illeszkedik be, nálunk azonban nem: a polgári mintázatok nem részei a nemzeti habitusnak (Hadas 2018a: 156, 159).

A nemzeti habitus kiformálódását illetően három periódusról, a 19. századot megelőzőröl, a hosszú 19. századiról és a 20. századiról beszél. Ami a 19. század előtti fejleményeket illeti, felidézi Szücs Jenő nevezetes tételeit Magyarország geopolitikai helyzetéről. Ez „külső kényszerként határozza meg a lehetséges strukturális variációk és az általuk kondicionált beállítódások körét" (Hadas 2018a: 156). Ebből a geopolitikai különbségből adódik egy adaptációs különbség is: ami a Nyugaton 500 év alatt valósult meg, az itthon 150 év alatt. Így érthető módon más lesz (Hadas 2018a: 157). Végül különbség az állam túlhatalma is: nálunk ez sokkal erösebb, mint Nyugat-Európában (Hadas 2018a: 157).

\section{Homológ rendszerek és a Fidesz „sehol”-ja}

A szerző a 20. századot elemezve három rendszerváltást (1919, 1945 és 1990) vet össze. Megállapítja, hogy ezek között „erős strukturális homológia” létezik (Hadas 2018a: 160), azaz: valamennyi átmenet után nagyjából ugyanaz a politikai és társadalomszerkezet ismétlődik. A következő tényezők tanúskodnak erről: 1 . Bukik az a világrendszer, amelynek addig Magyarország is részese volt. 2. A rendszerváltásokat mindegyik esetben külső erők kényszerítik ki (az antant, a Szovjetunió, illetve a nyugati nagyhatalmak). 3. Egyszer sincs megvívott forradalom. 4. Megszakad az a fejlődés, amely az elöző korszakban kezdődött el. 5. A régi vezető elitek kikerülnek a hatalomból, és a helyükre (ha nem is azonnal, hanem némi idő elteltével) „parvenü elitek” kerülnek (Bethlen után Gömbös, a Rákosi-korszakban alacsony 
sorból érkező munkások; illetve a Fidesz a 2000-es években. Hadas ezt követően a legrészletesebben ezt az utolsó szakaszt, a 2010-től máig tartó Fidesz-periódust elemzi). ${ }^{1}$

Megvallom, ezt a részt tartom a dolgozat legkevésbé sikerült, sőt sikerületlen részének. Mert addig nincs bajom, amíg analógnak (az ő szavával: homológnak) tekintjük az egyes átmenetek utáni helyzeteket. Magam is úgy vélem, nagyon sok (és valóban strukturális) hasonlóság mutatható ki az egyes rendszerváltások utáni új helyzetekben. Csakhogy a 2010 utáni korszak értelmezése egy hűvösebb és tárgyszerübb megközelítésből átmegy egy meglehetősen tendenciózus és egyoldalú Fidesz-leminősítésbe. Nem az a gond itt, hogy a szerző látványosan ki nem állja ezt a pártot és kormányzását, hanem az, hogy itt az érvelö-értelmező hanghordozás valami másba csap át. Az egyik magyarázó elve, hogy az elmúlt száz év három nagy rendszerváltása után fölkészületlen (az ő szavával: parvenü) elitek kerülnek hatalomra (Hadas 2018a: 160). Legalábbis az első és a harmadik rendszerváltás után, s azoknak sem mindjárt az elején. Összehasonlításában az 1930-as évek kerül szoros rokonságba a 2010 utáni időszakkal. Ahogyan Gömbös sem a hagyományos arisztokráciából vagy politika elitből jön, úgy a Fidesz sem. Söt a Fidesz egyenesen a „seholból jön” (Hadas 2018a: 161). A szerző három erkölcsi örökséget is felvillant, amelyek valamelyikét úgymond felhasználhatta volna a Fidesz, de mivel kompakt módon egyik se létezett, így egyikre se tudott ráépülni. Nem tudta átvenni a régi arisztokrácia becsületkánonját, a középosztály erénykánonját vagy az alsó osztályok munkaetikáját. De nem csak arról van szó, hogy ezek a minták nem léteztek, hanem arról is, hogy a Fidesz egyik társadalmi kategóriához sem állott közel, s tulajdonképpen nem is írható le szociológiailag. Nem csoda hát - következtet a szerző -, hogy a Fidesznek nincs is erkölcse, vezetöinek pedig nincsenek erkölcsi skrupulusai (Hadas 2018a: 161).

Itt azonban máris két súlyos ellenvetés tehető. Az egyik: ha a Fidesz a „seholból” jött, mindez miért nem volt zavaró, mondjuk, az 1988-tól 1994-ig tartó időszakban, s miért csak az után, amikor a Fidesz levált a liberális pólusról? Amíg a Fidesz liberális volt, addig nem volt érdekes a szociológiai korlátozottság? Másfelöl, ha az említett csoporterkölcsök egyikét sem birtokolja ma a Fidesz, az valóban erkölcsnélküli álláspontot jelent-e? Hadas egyértelműen így gondolja, amit például az ilyen mondatok jeleznek: „A lelkiismeret számára (mármint a Fidesz számára - Cs. E.) a gyengeség indikátora”. Nos, azt hiszem, ezzel korántsem intézhető el ez a kérdés. Sőt éppenséggel az lenne célszerü, ha a Fidesz (vagy tágabban a jobboldal) álláspontját is képesek lennénk erkölcsi álláspontnak tekinteni. ${ }^{2}$ Tudom, ez sokak számára lehetetlen, de mégis. Merthogy ha valóban az a célunk, hogy a magyar politika száz évének folyamatáról releváns tanulságokra jussunk, akkor kerülnünk kell a leegyszerüsítő, a politikai kiszólások kategóriájába kerülő megállapításokat.

\section{Gyülöletközösségek láncolata}

Ráadásul a tanulmány legvitathatóbb állítása (mintegy az egész dolgozat összegzése) is itt található, mégpedig az, hogy voltaképp a három 20. századi korszakot nem csupán strukturális hasonlóságok kötik össze, hanem az is, hogy mind a háromban egy „gyülöletközösség” müködik, s Magyarország voltaképpen emiatt nem tud egyről a kettőre jutni. A szerző persze

1 A szerző tanulmányának ezt a részét külön is megjelentette az Élet és Irodalomban (lásd: Hadas 2018b). Az erre adott válaszom ugyancsak ebben a lapban jelent meg (Csizmadia 2018).

2 A bal- és a jobboldali erkölcsi álláspontok különbségéről - és egyáltalán: létezéséről - lásd Kolnai (1997). 
igyekszik érvelni amellett, hogy ez így van, de véleményem szerint a bemutatott adalékokból nem vezethető le a gyülöletközösség állandóan visszatérő kategóriája. Mindegyik rendszer talál magának külső-belső ellenfelet (a Horthy-korszakban ilyen ellenfél a szomszéd népek és a zsidók; a kommunizmusban a Nyugat és a kizsákmányolók; 1990 után a kommunisták, majd napjainkban újra a zsidók és a migránsok) (Hadas 2018a: 163. o.). Ezek a szerző szerint „fiktív célcsoportok” (Hadas 2018a: 163), azaz mintha azt állítaná, hogy az egyes rendszerekben mindig a politikai irrealizmus működik, amikor ezeket kijelölik. De még ha ez így is lenne - szerintem nincs így -, abból nem következik a gyülöletközösség fenoménje. Hanem az, hogy a szerző szerint lényegében minden rendszerben csak egyetlen mérvadó cselekvő van, a hatalom, és rajta kívül az összes többi nincs befolyással a folyamatok alakulására. Ám ha ez így van, az megint magyarázatot követelne: hogyan lehetséges, hogy egyetlen más csoport, réteg sem tudja befolyásolni a politikai folyamatokat?

A városok és a polgári fejlödés hiánya, mint generális magyarázat, nem elégséges a gyülöletközösség létrejöttének igazolásához, illetve csak ahhoz elégséges, hogy a mélymúltat ne - mint Elias - folyamatként, hanem mégiscsak állapotként írjuk le. Ebben a megközelítésben ugyanis a folyamatok (ha vannak is) mindig ugyanoda jutnak, és lényegében nem is folyamatok vannak, hanem predeterminált állapotok. Hiányolom tehát, hogy az eliasi folyamatelemzés nem bontakozik ki, s elmarad a szereplök közötti kölcsönhatások (ugyancsak Elias által olyannyira fontosnak tekintett) vizsgálata is, illetve túlságosan csak az összes korszak parvenü elitjeiből vezetődik le a gyülöletláncolat és gyülöletlogika. Ha azonban csak folyton egyetlen szereplő mozgása az érdekes, akkor felmerül a kérdés, mi van a többiekkel, hogyan lehet, hogy a mindenkori parvenük mint kés a vajon mennek keresztül a társadalmon, és hagyják lenyomatukat korukon.

Itt tehát lényegesen összetettebb társadalom-, illetve habitusrajzot vártam volna, mert a leírtakból persze logikus, hogy „nincs remény!”, de engem nem ennek megállapítása érdekelt volna, hanem az, hogy a különféle társadalmi csoportok interakciójában mégiscsak hogyan áll össze valami, amit (anélkül, hogy reménytelennek minősítenénk) sajátosan magyarnak mondhatunk.

Ezt a „sajátosan magyart” - érzésem szerint - mélyrehatóbban találjuk meg másutt. Ezért forduljunk is egy másik, igaz, jóval régebbi szerzőhöz.

\section{A jelenig ható mélymúlt egy klasszikus interpretációja: Prohászka Lajos}

Hadas Miklós fentiekben kifejtett nézetei alapvetően a Szűcs Jenő-i régióértelmezéshez (Szücs 1983) kapcsolódnak, és ezt hozzák vissza az emlékezetünkbe. Ez a fajta (a legátfogóbban Wallersteinnél jelentkező) világgazdaság-elmélet (Wallerstein 1983) az átmenet után jószerivel feledésbe merült, mert a demokratizálódás új narratívája egyáltalán nem a geopolitikai komponensekre (azaz Magyarország és a külső közeg összehasonlítására) koncentrált, mint inkább a demokratizálás belső intézményi feltételeire. Fel sem merült, hogy a történeti kondícióknak (s azon belül a nemzeti habitus történelmi alakzatainak) a továbbiakban jelentőségük lesz. Viszont ma már egyértelmü, hogy ezek a történelmi tényezők ismét előkerülnek, és elég nagy magyarázóerővel bírnak.

Láttuk, hogy Hadasnál két meghatározó értelmezési irány van. Az egyik, hogy a magyar politikai fejlődésből strukturálisan kimaradtak olyan komponensek, amelyek Nyugat-Eu- 
rópában meghatározóak voltak. Két ilyen alakzat a város és a polgárosodás. A másik, hogy a strukturális deficitek miatt a különböző rendszerváltások nem tudják kifutni magukat, mert mindig ugyanoda jutnak, hogy hiányoznak a történelemben kiformálódó megfelelő magatartásformák. Ezért aztán dolgozata legföbb állítása, hogy a parvenü elitek számára nyílik meg a játéktér, s ezek „gyülöletrendszereket” hoznak létre. Ide konkludálva azonban (ahogy már mondtam) eléggé mechanikus lesz az elemzés, és ráadásul egyoldalú is. Épp ezért érdemes - megőrizve Hadas elemzésének magvát - beemelni a vizsgálatba egy másik szerzőt, Prohászka Lajost, aki a 20. század 30-as éveiben foglalkozott a nemzeti jellem, illetve habitus témájával.

\section{Prohászka Lajos: A vándor és a bujdosó (1936)}

Prohászka könyvének egyik középponti fogalma a magyar történelemben folyamatosan jelen lévő függetlenségvágy, mely gyökeresen más, mint a németek (a „vándorok”) függetlenségvágya. A német szabadságvágy egy eszme, a magyar szabadságvágynak azonban ehhez az absztrakt felfogáshoz semmi köze (Prohászka 1936: 92). Hozzáteszi még: nemcsak arról van szó, hogy a függetlenség absztrakt és gyakorlatias eszméje különbözik, de arról is, hogy a függetlenség mindig „pillanatnyi”, és bármikor újra harcolni kell érte. Ez folyamatos energiabefektetéssel jár, és közömbössé teszi a magyarságot „a történelemalakítás nagy pathosza iránt” (Prohászka 1936: 93). A szerző hosszasan foglalkozik ennek a permanens „harci állapotnak” a leírásával, illetve annak bemutatásával, hogy - miközben a magyarság „megható igyekezettel” törekszik a Nyugat felé fordulni (Prohászka 1936: 84), folyamatosan harcra kényszerül. Soha nem akarja igazán a harcot, jellemétől idegen bármilyen nagy eszme nevében felkelni, ugyanakkor időnként valamiért mégis harcok közepében találja magát. Talán épp az ország kicsi mérete és elkülönültsége az ok, illetve az, hogy mások mindig szemet vetnek ránk, mindenesetre e harcok a függetlenség megőrzéséhez, mások uralkodásának megakadályozásához kellenek. Egy eredendően passzivitásra hajlamos társadalom önvédelméről van tehát itt szó, s már csak emiatt sem lehet Magyarország teljesen nyugati társadalom, hiszen annak lényege a mások feletti uralkodás (a magyarság pedig, Prohászka szerint, soha nem akart más népek felett uralkodni) (Prohászka 1936: 93).

$\mathrm{Az}$ a harciasság tehát, ami a nyugati társadalmakat űzi, egy eszme, a magyar harciasság viszont egy, a körülmények kiváltotta kényszer, miközben a társadalom normálállapota a passzivitás: „Mintha a meglevőnek a megőrzésében, konzerválásában kimerülne egész aktivitása, a saját kezdeményezésű változástól ellenben visszahőköl” (Prohászka 1936: 96).

\section{A harc fogalma és intenzitása}

A két fogalmat (szabadság és harc) tehát így összegzi nekünk a szerző: „miként a magyar szabadságeszmének, úgy a magyar harcoknak is más a metafizikai háttere, amelyet a nyugati népek azért nem érthetnek meg, mert a saját harci akaratuk metafizikai alapjaiból vonják szemléletük körébe" (Prohászka 1936: 102). Azt is írja továbbá Prohászka, hogy a harc nem valami magyar specifikum, hiszen más népek is harcok sokaságát vívták meg történelmük során. Âm - s ez a mai magyar politika megítélése szempontjából is érdekes lehet - a harcnak „nálunk egészen más, az életformával szorosabban összefüggő jelentősége van, mint bárhol másutt Nyugaton" (Prohászka 1936: 101). Míg Nyugat-Európában harcolni kellett egy célért, és a harc során meg lehetett csillogtatni harci erényeket, nálunk egyikről 
sincs szó; a harc mindig kényszerű, illetve hiábavaló a magyar történelemben (Prohászka 1936: 103). Hadd kapcsoljam ide - mert ideillik -, hogy a Nobel-díjas Kertész Imre A néző címü esszékötetében (Kertész 2016: 210-211) arról beszél, hogy Magyarország „sosem élt keresztény kultúrában”. Szerinte itt csak papoltak a kereszténységről, de az ország évszázadokon át „pogány” maradt. S miben nyilvánult meg ez a pogányság? Hogy „kívül esett a keresztény mítoszvilággal összefonódott legendakörön... nem érintették nagy lelki forradalmak... misztikus őrjöngések, itt nem hagyott nyomokat a katolikus válság... itt még csak lovagkor sem volt, ez a nagy érzelmi forradalom, amely piedesztálra emelte a nőket, és elmaradt a felszabadító reneszánsz, illetve annak lelki és intellektuális következménye, folyománya”. Lelki forradalmak, misztikus őrjöngések, katolikus válságok, lovagkor - mind hiány, a harcos történelem hiányai.

Van azonban helyettük - s visszatérek Prohászkához - bőszültség. Szemben azzal, amikor a nyugatiak harcolnak, a magyarok a harcban - mert hiszen ez nem természetes számukra bőszülten vesznek részt, s éppen ez a kategória is a kelet-nyugati helyzet lelki és jellembeli kifejeződése. A harc egyetlen motívuma nálunk - mert kicsi és mások által folyton meghódítandó ország vagyunk - a már említett függetlenségvágy. Mivel a magyarság mindig másoktól elzárva, egy külön katlanban élt, függetlensége megörzésére törekedve, egyedüliségét élvezve bőszülten kellett rávetnie magát a „rátörő világra” (Prohászka 1936: 104).

A bőszültség tehát következmény, mégpedig a nyugatitól eltérő fejlődés következménye: a magyar „nem fejezhette ki magát a tőle különböző nyugati élményformáknak megfelelően. Ráadásul soha nem (mint nyugaton) elvekért folyt a bőszült küzdelem, hanem az elvek voltak a küzdelemért. „Nincs nép, amely ádázabb harcot folytatott volna elveiért, s ugyanakkor könnyebben adta volna fel elveit, mint a magyar” (Prohászka 1936: 106).

Voltaképpen könyvének ez a része egyértelmüen oda jut, hogy a magyarság - történelmi, geográfiai és társadalmi adottságai miatt - nem tudott olyan fejlödést produkálni, mint a nyugatiak. Míg a nyugati országok fejlődése mindig absztrakt elvekből (akár például a nyugati erények és harci készségek megmutatása) következett, s mindig a „végtelen” felé tört, addig nálunk a fejlődés mindig külső tényezők hatására következett be, $s$ az állandóság és a nyugalom megteremtésére irányult. A magyar nem ismeri a spontán és organikus fejlődést: „Fejlődése mindig lökésszerűen, mondhatni erőszakosan, külső tényezők hatására jött létre” (Prohászka 1936: 88). Voltaképp egy sajátos kettősséget ír le: a magyar egyszerre akarja a nyugalmat és a külső hatásokat. Ennek pedig végső megnyilvánulása, hogy minden ódzkodása és lázadása ellenére „befogadja” a külső (ez esetben: német) hatásokat: „A vándor az ellenállásokon keresztül is idehozza és vérébe oltja a feszültséget, úgyszólván »belevándorol « a magyar történetbe eszméivel és intézményeivel, problematikájával és ethoszával, és ezzel akarva, nem akarva sorsává válik" (Prohászka 1936: 89). ${ }^{3}$

\section{Az oligarchizálódás}

Nagyon érdekes még, amit Prohászka egy manapság is gyakran előkerülő fogalom, az oligarchia kapcsán mond. Ez a fogalom szorosan összekapcsolódik nála a fent említett harccal. Ugyanis az „életmegtartás” állandó kihívása fejleszti ki a politikai elitben, mi több, az egész

3 A „sors” kifejezés a könyv egyik alappillére. Könyve elején a szabadságot olyan valaminek tekinti, amit a „misztérium fátylai” rejtenek; ezzel szemben a sors a „valóság táblája, róla olvasni lehet” (Prohászka 1936: 17). Később pedig azt írja, hogy a német a vándor, és a magyar neki történelmi társa a történelmi sorsban (Prohászka 1936: 84). 
társadalomban az oligarchikus vonásokat, ami aztán túléli önmagát, és nemzedékről nemzedékre öröklődik (Prohászka 1936: 107).

Prohászka megállapítja, hogy szó sincs valamiféle „örök” és mindtől független nemzeti sajátosságról, arról, hogy az oligarchizálódás valamiféle magyar karaktervonás lenne. Jól látja, hogy történelme bizonyos pontján az oligarchia Európában mindenütt létrejött. Ahogy írja: az oligarchikus berendezkedés Európában „bizonyos kor és bizonyos történelmi helyzet szülötte”. Franciaországban például az oligarchia a központosító hatalom kiindulópontja. Nálunk azonban - ellentétben a nyugati példákkal - nem időhöz kötött, hanem - hatalmi rendszerként - túléli magát, és végigvonul a történelmen: „az oligarchia a magyarságnál nem egyszeri történeti jelenség, hanem inkább természetes életstílus, lélekforma” (Prohászka 1936: 108).

Ráadásul - s talán ez a legérdekesebb - nem csak a felső körök sajátossága: „az egyén magát minden körülmények közt úrnak érzi, abban a tudatban él, hogy vannak alantállók, akiknek törvényt szabhat, akikkel rendelkezik". Ilyen értelemben egy mindent átfogó oligarchikus hálóról beszélhetünk, amelyben még a paraszt is „apró khán” (így az eredetiben!) (Prohászka 1936: 108).

A nyugatival ellentétes módon az önmagát túlélő oligarchizálódás tehát egy sajátos, az egész társadalmat behálózó hatalmi konstrukció, amelynek az az alapja, hogy nálunk nem volt nemzeti abszolutizmus. Ha ugyanis ez lett volna, az magával hozta volna a polgári életforma kialakulását és háttérbe szorítja az oligarchikus hajlamot (Prohászka 1936: 109). Mivel azonban ilyen nemzeti abszolutizmus nem létezett, ahelyett, hogy egy felülről megtámogatott s egységes polgári társadalom jött volna létre, a társadalom széttagolódott, ily módon az oligarchizálódást nemcsak felülről, hanem alulról is fenntartották (Prohászka 1936: 109). Hogy egy ilyen, alulról is fenntartott oligarchisztikus modell mennyire más, mint a nyugati, arról Alexis de Tocqueville már 1830-as amerikai útja nyomán írott könyvében tájékoztat minket: Amerikában egy ember helyét nem az dönti el, hogy a hatalmi hierarchiában alul vagy fölül áll. ${ }^{4} \mathrm{~S}$ azért nem, mert a polgárosodás, az autonóm állampolgárrá válás a társadalom egészét áthatja, s evidenssé teszi például annak a kategóriának a megszünését, amelyet Prohászka pár sorral feljebb „alantállónak” nevezett. Ilyenfajta fejlődés azonban nálunk - úgy tetszik - nem játszódott le, vagy ha meg is indult, nem volt eléggé mélyreható, és nem szüntette meg a társadalom - történelmileg kialakult - oligarchikus szerveződési módját.

\section{Abszolutizmushiány}

Ezt konstatálva írja Prohászka: „A magyar az életet egyáltalán csak mint egyéni kiváltságokkal felruházottat tudja értékelni. S itt nem is annyira magán a kiváltságon van a hangsúly, mint inkább a kiváltságoknak mástól való elismerésén. Ez is egyebek között oka annak, amiért a Nyugat őt soha sem tudja megérteni: mert alkotmányformának minősíti, és ezzel természetszerüleg az egyetemes európai fejlődés mögött visszamaradottnak érzi azt, ami nála életforma, az alapélménynek egyik spontán kifejezési módja” (Prohászka 1936: 110). De persze miközben Prohászka szeretné megkülönböztetni az alkotmányos fejlődés és az életforma fogalmait, maga teszi egyértelművé, hogy a magyar fejlődésben a kettő igenis összecsúszik. „A kiváltságért folytatott harc - írja - egybeesik az alkotmányért, a nemzeti

4 Az úr-szolga viszonyról ezt írja A demokrácia Amerikában című könyvében: „A demokrácia nem zárja ki az emberek e két osztályának létét, viszont megváltoztatja gondolkodásukat és módosítja kapcsolataikat” (Tocqueville 1983: 437). 
függetlenségért vívott harccal; az oligarchikus akarat válik ezzel a közösség egészének, az ő függetlenségvágyának kifejezőjévé...” És tovább: „A Nyugat soha nem képes felfogni, hogy a magyar mindig csak »követel «, mert agresszivitást lát mögötte; holott ez az örök követelés nem agresszív lelkületből folyik, hanem inkább depresszióból: követel, mert általa védekezik.” És ezek után jön a még fontosabb megállapítás: „Ha az abszolutizmus nálunk is, mint a Nyugaton mindenütt, nemzeti talajon nö, akkor annak védszárnyai alatt talán nálunk is kialakult volna egy polgári életforma, amely az oligarchikus hajlamot lassanként háttérbe szorította, esetleg el is nyomta volna. De mert idegenből jött és a kiváltságokkal együtt a magyarságot a maga létében fenyegette, azért az oligarchikus hajlamot csak megerösítette, sőt kiélezte. Az az abszolutizmus tehát, amely mindenütt Európában kulturális fellendülést hozott, az elesettségből emelte fel a népet, nálunk az ellene való kényszerü küzdelemben a nemzet legjobb erőinek pusztulására vezetett, és az oligarchikus életforma, amely a nemzeti függetlenség és a fennmaradás hordozója volt, szükségképpen visszavetett az európai fejlödés sodrában" (Prohászka 1936: 110).

\section{Attila-álmok és Európa-akarás}

Prohászka könyve tehát egy komplex történetfilozófiai magyarázatot nyújt Magyarország és a Nyugat eltérő karakteréről. Ehhez két megjegyzés tartozik még. Az egyik, hogy az ő számára is alapvető a sokak által említett Szent Korona-tan, amely egy nyugalomra, függetlenségre, szabadságra vágyó ország számára a legnagyobb megtartó erővel bír. A tan - ahogyan fogalmaz - „erősebb megkötő hatalomnak bizonyult a legrátermettebb, a legbölcsebb, sőt a legszentebb személyiségnél” (Prohászka 1936: 121).

A másik megjegyzés: Prohászka látja azt is, hogy ebből a történeti fejlődésből két végletes személyiségtípus formálódik ki: az egyik, amelynek „Attila-álmai” vannak, a másik, amely „Európa-akaratú”, s mindkettő megpróbálja a másikat háttérbe szorítani (Prohászka 1936: 128). Eddig a leírás - ha fogalmilag nem is, de - megegyezik sokak leírásával, akár azokéval, akik haza és haladás permanens konfliktusáról írnak.

Csakhogy a szerző azt mondja, hogy itt nem két külön arcról van szó: „a két arc úgy egymáshoz tartozik, hogy egyiknek sincs a másik nélkül kifejezése... Nincs külön keleti és nyugati magyar... valahogy a kettő mindig egyszerre és egymásban van... a "nyugati« szellem épp úgy lehet tespedtség és ellenállás hordozója, mint ahogy viszont a sokat gáncsolt »keleti« magatartás a megújulásé” (Prohászka 1936: 128).

\section{A mai magyar helyzet történelmi perspektívából: egy politológiai múltértelmezés néhány eleme}

A fentiekben igyekeztem megvilágítani, miben értek egyet Hadas Miklóssal, és miben nem. A dolgozat hátralévő részében szeretnék kifejteni egy alternatív múlt- és jelenértelmezést. Ehhez három alapvető kérdést kell röviden érintenem. 1. A magyar politika folyamatos zsákutcássága, avagy lehetséges-e a magyar politikát normálisnak tekintenünk? 2. Mit mondanak nekünk a hazai rendszerváltások utáni viszonylag kiszámítható visszarendeződések? 3. Magyarázhatunk-e történéseket egy kitüntetett szereplő magatartásának megváltozásából, avagy szerencsésebb-e a politikai szereplők közötti kölcsönhatásokról beszélni? 
Hadas leírásának érdeme, hogy (mint már megállapítottam) ráirányítja a figyelmünket jelen és múlt egybekapcsolására. Ezzel már önmagában is többet tesz azoknál, akik az átmenet utáni fejlődést a múlttól elszakítva - ahogy én szeretem nevezni: jelencentrikusan - igyekeznek vizsgálni. A múlt vizsgálatában azonban a szerző - nekem úgy tűnik - addig jut, hogy a magyar történelemben zsákutcákon keresztül bukdácsoltunk, s így törvényszerủen következett be az újabb zsákutca a Fidesz-érában is.

Nézzük vázlatosan, mi támasztaná alá a zsákutcatézist. Talán a legerösebb érv az - s erre is utaltam az első részben -, hogy a magyar fejlődés két ponton is (városiasodás, polgáriasodás) különbözött a nyugatitól, ez pedig alapvetően meghatározta a lehetőségeket, és mintegy strukturális korlátként zárta be a mindenkori magyar politikát. Ebben a szerzőnek, meglehet, igaza van, de ha így is van, miért kellene ettől zsákutcásnak (vagy akár abnormálisnak) nevezni a magyar fejlődést. Hajlamos vagyok azt mondani, hogy ez éppúgy normális, mint más országok fejlődése - már amennyiben hajlandóak vagyunk egy „kis” engedményt tenni. Ez a kis engedmény az, hogy a magyar fejlődéstöl nem ugyanazt várjuk, mint a külföldi mintaországok fejlődésétől, és képesek vagyunk a nyugatitól való eltérést nem veszteségként, torzulásként elkönyvelni.

Ez persze nem könnyü, de mégsem látok más lehetőséget. Jó lenne reprodukálni a nyugati fejlődés reprezentatív intézményeit és magatartásmódjait, csakhogy ez azért nem sikerült régen, és azért nem sikerül ma sem, mert maga a közeg csak részben nyugati. A probléma tehát nem az, hogy hiányoztak volna (vagy hiányoznának) azok az elitek, akik szeretnék ezt a nyugatosodást, hanem az, hogy önmagában a felzárkózás szándéka és motívuma eltérő a nyugati régió eredeti mintájától.

Ettől azonban ez a fejlődés nem torz, és különösen nem reménytelen. Annál inkább arra ösztökél viszont, hogy mind alaposabban megismerjük, majd pedig értsük is meg. Úgy hiszem, az elmúlt 28 év ennek a hosszú távú fejlődésnek a tárgyszerủbb megismeréséhez nemigen vitt közelebb. Az átmenet utáni korszak jelencentrikussága túlságosan arra koncentrálta a figyelmünket, hogy a jelenben valami jól van-e vagy sem, s persze aki arra voksolt, hogy „nincs jól”, az ehhez már könnyen társította azt a toposzt is, hogy ismét zsákutcába kerültünk.

Ezzel szemben én azt gondolom, hogy el kell kezdenünk Magyarország politikai fejlödését az adott kereteken belül normálisnak tekinteni. Ez nem lesz könnyü, s csak akkor sikerülhet, ha ezt a fejlődést nem mint nemzeti fejlödést tekintjük, hanem folyamatosan öszszehasonlítjuk más országokéval. Szente Zoltán például nagy monográfiát írt (Szente 2011) a kormányzásról a dualizmus rendszerében, ám könyve sokkal több ennél: nagyszabású európai kitekintés és összehasonlítás. S ebben az összehasonlításban Magyarország nem is szerepel olyan rosszul.

\section{Az átmenetek utáni visszarendeződések kérdéséhez}

Magam is úgy gondolom, hogy a magyar 19-20. századi politikai történések nem logikátlanok, és kirajzolódik belőlük valamifajta visszatérö rend. Ennek vannak konstans elemei. Az egyik, hogy az új rendszer addig teljesítőképes, ameddig számára a külső erőtér kedvező. Most csak egy elemet ragadnék ki, s ez a pártrendszer. Fontos észlelnünk a hasonlóságokat az 1867-tel kezdődő modern pártrendszerek és a mai között. Szinte minden átmenet 
után domináns pártrendszer jött létre. Ez azt jelenti, hogy bár formálisan sokpártrendszerek müködtek (a Kádár-rendszert leszámítva), közülük egy mindig kiemelkedett, és tartósan birtokolta a kormányzati hatalmat. Ez is egy a mélymúltból származó történelmi vagy magatartási tradíció, amelyet például Bibó István is elemzett.

Természetesen ez a múlt által meghatározott pártelrendeződési mintázat eltünni látszott 1990-ben, amikor a külső erőtér nagymértékben azt a nyugati mintát állította előtérbe, hogy a domináns pártrendszer helyett egy egyensúlyelvü pártrendszer legyen, azaz: négyévenként történjék csere a kormányzók szintjén. S így is történt: 1990 és 2002 között minden választást más párt nyert és úgynevezett rövid ciklusú váltógazdálkodás alakult ki. Ámde a történelmet itt se lehet teljesen kiiktatni, merthogy 2006-ban megtörik a négyévenkénti demokratikus váltógazdálkodás varázsa, és az MSZP-SZDSZ-koalíció egy második felhatalmazást kap. Régóta úgy gondolom: ez nem véletlenszerü, hanem nagyon is a társadalom mélyebb motivációiból következő változás, amit csak akkor értünk meg, ha a jelent és a múltat egységben kezeljük, és képesek vagyunk átlátni, hogy míg az első bő 15 évben a jelen a múlt fölé tud kerekedni, addig ezt ekkor már nem képes megtenni, és a múlt kopogtat az ajtón. De fontos, hogy nem egy abnormális, egy anakronisztikus, egy torz múlt, hanem egy teljesen normális. A magyar társadalom először a baloldali-liberális oldal felé jelenti be igényét, hogy a történelmet vegye figyelembe. Ami itt azt jelenti, hogy kapjon lehetőséget egy hosszabb kormányzásra. S ha valami, hát a hosszú, dominánspárti kormányzás a magyar politikatörténet legidőtállóbb öröksége. Azt is mondhatnánk, hogy Magyarországon az emberek mindig az erős, nagy pártoktól várták a stabil kormányzást, míg a széttöredezett ellenzéki pártokat (bár szellemi befolyásukat elismerték) nem tekintették kormányképesnek.

Mindebből az következik, hogy a Fidesz 2010 utáni hatalomra kerülése - a mélymúlt és a pártpolitikai tradíciók alapján - nem írható le abban a narratívában, hogy a „seholból” jött parvenü elit ül tort, ráadásul mellőzve mindenféle erkölcsi skrupulust. Nem, erröl szó sincs: a Fidesz tökéletesen beleillik abba a komplex pártarénaképletbe, amely nálunk mindig is volt. E képlet egyik oldalán a nagy (de stabilitást nyújtó) állampárt, a másik oldalán a szétaprózott és kormányképtelen ellenzék áll. E tradíció ismerete nélkül, attól tartok, bajos lesz a mai ellenzék harca is a kormányoldallal szemben, mint ahogy azok az elemzések is félrecsúsznak, amelyek ki akarják iktatni a mélymúltnak ezt a szegmensét a mai politika értelmezési tartományából.

\section{Az egyszereplös magyarázatok ellen: a politikai aktorok kölcsönhatása}

S végül megemlítem, hogy számomra a legizgalmasabb probléma mégiscsak a rivális elitek magatartásában megjelenő tartalmi elem. Mit értek ezen? Egyszerűen szólva a külső erőtérhez való viszonyt. Ha csupán annyit mondunk, hogy az átmenetek után mindig megjelennek az alacsony nívójú, erkölcs nélküli elitek, nem mondunk semmit arról, hogy ezt hogyan tehetik meg, s miért nincs a társadalomnak elég ellenállóereje, hogy ezt megakadályozza. Nagyon egyszerüen szólva: vajon miért nem tud az átmeneteket levezénylö elit konszolidálódni?

A kérdés megválaszolása egy nagyon lényeges - és a külső erőtérrel szorosan összefüggő kérdéshez vezet el bennünket. Ahhoz, hogy a külső erőtér korántsem mindig és hosszabb távon egyértelmű orientációs pont. 1990-ben úgy tűnt, hogy a Nyugat orientációs vonzása egyértelmü, de ha akkor olvastuk volna Prohászkát (vagy épp az ebben az írásban nem említett Babitsot (2005 [1939]) és Joó Tibort (1940)), akkor tudtuk volna, hogy a mélymúltban 
volt egy nagyon erős törésvonal mintakövetők és mintaformálók között. Az elöbbi csoport - amelyet mi nyugatosként szoktunk meghatározni - azt tartja céljának, hogy mind teljesebben zárkózzunk fel a mintarégióhoz (általában az angolszász világot értve ez alatt). A mintaformálók a követés tárgykörében mindig szkeptikusak, sokkal jobb véleménnyel vannak Magyarország belső fejlődéséről, és azt gondolják, szó sem lehet egyoldalú mintakövetésről, mert a külső környezetet nekünk is formálnunk kell. Az előbbi csoportról, attitűdről és hagyományról szinte mindent tudunk, míg a másikról alig valamit. Pedig ez utóbbira is létezik egy masszív eszmetörténeti hagyomány, és ebből rekonstruálható megint csak egy normálisként - nem pedig torzultként - leírható magatartásforma. Szerintem ezt a mintaformáló tradíciót láthatjuk most újraelevenedni a Fidesz képében, és akármennyire is nem kedvelik sokan (s nagyon finom voltam) a Fidesz kormányzását, azt mégsem tehetjük meg, hogy ne próbáljuk megérteni a mélymúltból származó üzenetet.

Ez az üzenet az, hogy a haladó-retrográd dichotómia nem írja le a folyamatokat és a szereplők közötti kölcsönhatásokat. Nem tartom szerencsésnek, ha a múltból „kiválogatjuk” az úgynevezett haladó személyeket, eszméket és mozgalmakat, míg az ún. „retrográd” erőket „elrettento"” példaként mutatjuk fel. Ugyanezt látom a mai időket illetően is. Csakhogy így nem fogjuk megérteni a mélymúlt szerepét, illetve csak annyi lesz a tanulság, hogy a történelmi „rossz” jelenbeli „rosszra” konvertálódott.

A politikai szereplők közötti interakció abban segíthet, hogy megértsük: a rendszerváltás utáni mintakövetés miért bizonytalanodik el, és ez hogyan mozgósítja a kezdettől lappangó mintaformáló erőket, amelyek - a külső közeg megváltozásával - egyre több befolyáshoz jutnak, és voltaképp visszaállítják a magyar történelem dominánspárti képletét.

Elismerem, hogy - egy rendszerváltáskori kiindulópontról - mindezekkel nem könnyü megbarátkozni. De számomra van egy minden mást felülíró szempont: egy történeti-politikatudományi rekonstrukció számára szeretném jobban megérteni a történelem és a jelen nexusát. Nem mint zsákutcát, hanem mint normalitást. Mondandóm végkicsengése tehát: ebben a múltban számos elemet találunk, amely magyarázóerővel bír mindarra nézvést, amivel ma is találkoznunk. Ha nem rettenünk meg események, struktúrák és magatartások valóban összetartozónak tűnő láncolatától, akkor talán ezzel az örökséggel kezdhetünk valamit, s a reményt sem kell teljesen feladnunk.

\section{Hivatkozott irodalom}

Acemoglu, Daron és James A. Robinson (2013): Miért buknak el nemzetek? A hatalom, a jólét és a szegénység eredete. Budapest: HVG Könyvek.

Babits Mihály (2005 [1939]): A magyar jellemröl. In uő. Tanulmányok, esszék. Jankovics József (szerk.). Budapest: Kortárs, 514-553.

Carothers, Thomas (2002): The End of the Transition Paradigma. Journal of Democracy 13(1): 5-21. DOI: https:// doi.org/10.1353/jod.2002.0003.

Csizmadia Ervin (2017): A magyar politikai fejlödés logikája. Összehasonlitható-e a jelen a múlttal, és ha igen, hogyan? Budapest: Gondolat.

Csizmadia Ervin (2018): Trendek ereje. Élet és Irodalom (március 2.).

Hadas Miklós (2018a): Mi a magyar? Újratöltve - hetvennyolc év után. Replika (105): 153-171.

Hadas Miklós (2018b): Nincs remény! Vázlat a magyar nemzeti gyülöletközösség elmúlt száz évéröl. Élet és Irodalom (február 9.).

Joó Tibor (1940): A magyar nacionalizmus. Budapest: Athenaeum. 
Kolnai Aurél (1997): Erkölcs és politikai megosztottság. Századvég (5): 127-148.

Prohászka Lajos (1936): A vándor és a bujdosó. Budapest: Minerva.

Szente Zoltán (2011): Kormányzás a dualizmus korában. A XIX. századi európai parlamentarizmus és Magyarország kormányformája a kiegyezés után. 1867-1918. Budapest: Atlantisz.

Szűcs Jenő (1983): Vázlat Európa három régiójáról. Budapest: Magvető.

Tocqueville, Alexis de (1983): A demokrácia Amerikában. Budapest: Gondolat.

Wallerstein, Immanuel (1983): A modern világgazdasági rendszer kialakulása. Budapest: Gondolat. 
